\title{
Impact of the south Russia weather conditions on the fruitfulness coefficients of domestic breeding grape varieties
}

\author{
Anna Marmorshtein ${ }^{1 *}$, Valeriy Petrov ${ }^{1}$, Aleksey Lukyanov ${ }^{2}$, Anna Lukyanova ${ }^{2}$, and \\ Aleksandr Kovalenko ${ }^{2}$ \\ ${ }^{1}$ Federal State Budget Scientific Institution «North Caucasian Federal Scientific Center of \\ Horticulture, Viticulture, Wine-making», str. 40 Let Pobedy, 39, 350901 Krasnodar, Russia \\ ${ }^{2}$ Anapa Zonal Experimental Station of Viticulture and Wine-making - Branch of Federal State \\ Budgetary Scientific Institution «North Caucasian Federal Scientific Center of Horticulture, Viti- \\ culture, Wine-making», Pionerskiy avenue, 36, 353456 Anapa, Russia
}

\begin{abstract}
The issue of grape plants adaptation to current and future climate changes is acute. Agrobiological records conducted in vineyards at the beginning of the growing season show the possible productivity by the values of the fruitfulness coefficients ( $\mathrm{k} 1$ and $\mathrm{k} 2)$. The adaptation of plants is higher in varieties with high values of the fruitfulness coefficients, so it is important to determine their relationship with the weather conditions of the territory. The aim of this work was to study the influence of weather conditions in the south Russia on the grapes fruitfulness coefficients of thirteen Vitis Vinifera varieties of domestic breeding AZESVW and NCZSRIHV for the period 2007-2020 by the method of correlation analysis. A large relationship between the parameters of fruitfulness k1 and k2 with the temperature of the previous year (especially with the minimum air temperature and temperature range), and a smaller one with the characteristics of moisture availability, was revealed. The influence of winter meteorological conditions was noted in the correlation analysis of all the data, for individual varieties, due to frost resistance, the dependence was not significant. In general, there is a variety-specific correlation.
\end{abstract}

\section{Introduction}

The adaptation of the grape plant to the current and expected changes in climatic conditions is an important problem of viticulture and winemaking around the world. In this regard, studies of the vine reaction to the natural and anthropogenic agroecological conditions for the productivity and quality management of grapes and viticulture products are updated [1]. It is a common fact that the yield formation is started at the flowering of previous year in form of inflorescence primordium and their following differentiation [2]. Warm and sunny days are favorable environmental conditions for the initiation and differentiation of inflorescence, the reverse weather leads to the grapevine tendrils formation [3]. After the beginning of the dormancy low temperatures are important for overwintering buds. Optimal

\footnotetext{
* Corresponding author: am342@yandex.ru
} 
conditions for light, temperature and humidity are necessary for the formation and production of a high-quality yield during the growing season after inflorescences overwintering [4]. A common way to study the weather influence on grape plants is correlation analysis, as, for example, for the Rhine Riesling and Müller-Thurgau varieties in Luxembourg from long time series of observational data [5].

Anthropogenic factors include cultural practices aimed at grape realizing adaptive and productive potentials. Pruning shoots on grape bushes is one of the most important techniques in the yield formation. This operation is carried out in winter or early spring before the beginning of the grapevine bleeding [6]. During the growing season, green operations are carried out: breaking-off shoots, topping [3], forcing regrowth [6], leaf removal [7,8], thinning shoots (forming a shoots load on bushes) [9], etc. These techniques are more often performed in a complex [10-12]. The pruning procedure is influenced by embryonic fruitfulness data - the inflorescences/buds ratio and the inflorescences/fruitful buds ratio (always greater than or equal to 1) [13]. Changes in the shoots density depend on similar parameters - the fruitfulness coefficients $\mathrm{k} 1$ and $\mathrm{k} 2$. The fruitfulness coefficient $\mathrm{k} 1$ is the clusters/shoots ratio and the fruitfulness coefficient $\mathrm{k} 2$ is the clusters/fruitful shoots ratio (always greater than or equal to 1) [14]. The values of this coefficients depend on variety and determine their resistance to stressors. The higher the fruitfulness coefficients, the higher the plant's adaptation to environmental conditions and its resistance to stress factors.

The purpose of this work was to study the influence of weather conditions in the south Russia on the values of the fruitfulness coefficients of domestic breeding grape varieties to assess their adaptability.

\section{Materials and Methods}

The study of the weather conditions influence of the moderate continental climate's south Russia on the parameters of the grape fruitfulness coefficients was carried out according to observations at the ampelographic collection of the Anapa Zonal Experimental Station of Viticulture and Wine-making branch of the FSBSI NCFSCHVW from 2007 to 2020 and Anapa weather station's meteorological data from the website of the RIHMI-WDC (meteo.ru) from 2006 to 2020. The objects of the study were 13 Vitis Vinifera varieties of domestic breeding NCZRIH\&V and AZESV\&W: Alcor, Antaris, Barkhatnyi, Beysug, Granatovyi, Dostoynyi, Cabernet AZOS, Krasnostop AZOS, Kubanets, Litdar, Mitsar, Muscat Kubanskiy and Satsimler. The series length of fruitfulness coefficients varied from 7 to 13 years.

Meteorological parameters were determined for various periods that affect the initiation and differentiation of inflorescence primordium (according to the literature references): June (VI), July (VII), June-July (VI-VII), June-October (VI-X), June-November (VI-XI), the flowering-veraison of the previous growing season (FLO-VER). Also were used winter period, January-February (I-II) and the beginning of the following year growing season (IV).

The main meteorological parameters used in this work were: average (Avg T), maximum (Max T) and minimum (Min T) air temperatures, the sum of active air temperatures above $+10{ }^{\circ} \mathrm{C}($ Sum T10), the average air temperature amplitude $(\mathrm{A}=(\operatorname{Max} \mathrm{T}-\mathrm{Min} \mathrm{T}))$, the total precipitation (TP), the minimum soil temperature (Min Ts), the average relative humidity (RH), the Selyaninov hydrothermal coefficient (HTC). 49 parameters were used in total.

The meteorological parameters relationship with the fruitfulness coefficients was determined by correlation analysis. The correlation coefficients significance was checked by the Student's t-test at the significance level $\alpha=0.05$. 


\section{Results and Discussion}

The weather conditions of the studied period of 2006-2020 according to the Anapa weather station were characterized by high variability. The average air temperature for the JuneNovember period ranged from $+17.7^{\circ} \mathrm{C}$ in 2011 to $+20.6{ }^{\circ} \mathrm{C}$ in 2010 ; the total precipitation ranged from $92.1 \mathrm{~mm}$ in 2012 to $473.7 \mathrm{~mm}$ in 2013. In the most important period of the initiation and differentiation of inflorescence primordium (June-July) the average temperature was $+22{ }^{\circ} \mathrm{C}$ in 2006 and $+24.7^{\circ} \mathrm{C}$ in 2012 , the maximum temperature reached $+38^{\circ} \mathrm{C}$ in 2007 , the minimum temperature dropped to $+13.5^{\circ} \mathrm{C}$ in 2006 . The minimum winter air temperature varied from $-20{ }^{\circ} \mathrm{C}$ in 2012 to $-4.9^{\circ} \mathrm{C}$ in 2019 (Fig), the average temperature of January-February was below zero only in $2012\left(-0.4^{\circ} \mathrm{C}\right)$ during induced dormancy. The fruitfulness coefficients also varied from year to year - the minimum values were recorded in 2012 - average k1 was 0.39 ( 0 in the varieties of Muscat Kubanskiy and Satsimler, which means the complete absence of clusters), average k2 was 1.09 ( 1 in the varieties Kubanets and Litdar); the maximum value of k1 was in 2013 (1.37), k2 - in 2009 (1.68).

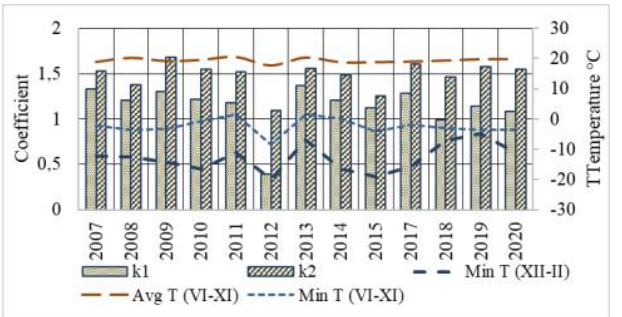

Fig. 1. Weather conditions and fruitfulness coefficients of the studied period (the average and minimum temperature of June-November is shown for the growing season of the previous year)

According to the correlation analysis for fruitfulness coefficient k1, 44 values of 441 were statistically significant, and in the case of the fruitfulness coefficient $\mathrm{k} 2$ - 33 values of 441 . These values characterized the correlation between the weather and the coefficients as moderate or strong (Table 1). Italics indicate parameters with inverse (negative) correlation. For the most part, the meteorological parameters that significantly affect these fruitfulness coefficients are represented by temperature characteristics (especially the range of air temperatures and the minimum air temperature), and the relationship in most cases is direct. There are variety-specific relationships. The negative effect of high temperatures on the varieties Dostoynyi and Muscat Kubanskiy is greater than on other varieties. The $\mathrm{k} 2$ of the Antaris variety is more affected by the temperature amplitude for different periods. High relative humidity of June-November period negatively affects the k1 value of Mitsar variet, but positively affects the $\mathrm{k} 2$ value of the Litdar variety. The Krasnostop AZOS variety values of $\mathrm{k} 1$ and $\mathrm{k} 2$ are affected by the total precipitation - negative correlation for June and positive correlation for January-February period.

Table 1. Characteristics of significant correlation coefficients of weather conditions with the fruitfulness coefficients $\mathrm{k} 1$ and $\mathrm{k} 2$ by varieties

\begin{tabular}{|c|c|c|c|c|}
\hline \multirow[t]{2}{*}{ Variety } & \multicolumn{2}{|c|}{$\begin{array}{c}\text { Moderate relationship } \\
(0,5 \leq \mathrm{r}<0,7)\end{array}$} & \multicolumn{2}{|c|}{$\begin{array}{l}\text { Strong relationship } \\
(\mathrm{r} \geq 0,7)\end{array}$} \\
\hline & $\mathrm{k} 1$ & $\mathrm{k} 2$ & $\mathrm{k} 1$ & $\mathrm{k} 2$ \\
\hline Alcor & A (VI-VII), A (VI-X) & $\operatorname{Min} T(V I-V I I)$ & & \\
\hline Antaris & Min T (XII-II) & $\begin{array}{l}A(V I I) \\
A(V I-X I)\end{array}$ & & $\begin{array}{l}A(V I-V I I), A \\
(V I-X)\end{array}$ \\
\hline Barkhatny & Min T (VI-XI) & $\begin{array}{l}\text { Min T (Flo-Ver), } \\
\text { RH (VI-XI) }\end{array}$ & & \\
\hline
\end{tabular}




\begin{tabular}{|c|c|c|c|c|}
\hline Beysug & $\begin{array}{l}\text { Avg T (VI-X), A (VI- } \\
\mathrm{X}) \\
R H(V I-X I), \\
\text { Min T (XII-II) }\end{array}$ & $\operatorname{Min} T_{s}(I V)$ & 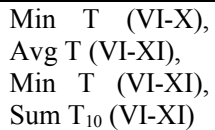 & $\begin{array}{l}\text { A (VI), A } \\
(\mathrm{VI}-\mathrm{XI})\end{array}$ \\
\hline Granatovy & $\begin{array}{l}\text { Avg T (VI-XI), Sum } \\
\mathrm{T}_{10}(\mathrm{VI}-\mathrm{XI}), \\
\text { Avg T (I-II) }\end{array}$ & $\begin{array}{l}\text { Avg } \mathrm{T} \quad(\mathrm{VI}-\mathrm{VII}), \\
\text { Sum }^{\mathrm{T}_{10}}(\mathrm{VI}-\mathrm{VII})\end{array}$ & Min T (VI-XI) & \\
\hline Dostoyny & $\begin{array}{l}\text { Max } T(\text { Flo-Ver }) \\
\text { Min T (VI-XI) }\end{array}$ & $\begin{array}{l}\operatorname{Max} T(\text { VI-VII), } \\
\operatorname{Max} T(V I I), \\
\operatorname{Max} T(\text { Flo-Ver })\end{array}$ & & \\
\hline $\begin{array}{l}\text { Cabernet } \\
\text { AZOS }\end{array}$ & Avg T (VI-XI) & $\begin{array}{l}\text { Avg T (VI), Max T } \\
\text { (VI), A (VI), } \\
\text { Sum } T_{10}(V I), \\
T P(\text { Flo-Ver) }\end{array}$ & Min T (VI-XI) & A (VI-XI) \\
\hline $\begin{array}{l}\text { Krasnostop } \\
\text { AZOS }\end{array}$ & $\begin{array}{l}\text { TP (VI), } \\
H T C \text { (VI), } \\
\text { Avg T (VII), } \\
\text { Sum T }_{10} \text { (VII), Avg T } \\
\text { (VI-X), } \\
\text { Min T (XII-II) }\end{array}$ & & & $\begin{array}{l}\text { A }(\mathrm{VI}-\mathrm{X}), \mathrm{TP} \\
\text { (I-II) }\end{array}$ \\
\hline Kubanets & $\begin{array}{l}\text { A (VI-X), } \\
\text { Min T (VI-XI) }\end{array}$ & Min T (VI-X) & & Avg T (I-II) \\
\hline Litdar & $\begin{array}{l}\text { A (VII), } \\
\text { Min T (VI-XI) }\end{array}$ & $\begin{array}{l}\text { A (VI-VII), } \\
\text { RH (VI-XI) }\end{array}$ & $\begin{array}{l}\text { A (VI-VII), A } \\
\text { (VI-XI) }\end{array}$ & $\begin{array}{l}\text { Min T (VI- } \\
\text { XI) }\end{array}$ \\
\hline Mitsar & $\begin{array}{l}\text { A (Flo-Ver), RH (VI- } \\
X I)\end{array}$ & & $\begin{array}{l}\text { A (VI-VII), RH } \\
(V I-V I I), \\
\text { A (VI-X), } \\
\text { A (VI-XI) }\end{array}$ & \\
\hline $\begin{array}{l}\text { Muscat } \\
\text { Kubansky }\end{array}$ & $\begin{array}{l}\operatorname{Max} T(V I I), \\
\operatorname{Max} T(V I-V I I), \\
\operatorname{Max} T(F l o-V e r)\end{array}$ & & & \\
\hline Satsimler & Sum $T_{10}(\mathrm{VI}-\mathrm{XI})$ & Min T (VI-X) & $\begin{array}{l}\text { Avg T (VI-XI), } \\
\text { Min T (VI-XI) }\end{array}$ & $\begin{array}{l}\text { Avg T (VI- } \\
\text { XI), Min T } \\
\text { (VI-XI), } \\
\text { Sum T }_{10}(\mathrm{VI}- \\
\text { XI) }\end{array}$ \\
\hline
\end{tabular}

41 values of 102 were significant in correlation analyze of all varieties with additional parameters (number of frosts, the beginning of flowering and the beginning of veraison). It should be noted that the moderate relationship of the fruitfulness coefficient $\mathrm{k} 1$ was with the minimum air temperature of June-November period. In other cases, the significant relationships were either weak, very weak, or there was no correlation with both positive and negative values (Table 2). Also, with a slight influence of winter conditions on the fruitfulness coefficients values for varieties, in general, there is a significant weak correlation with the average air temperature in January-February, a moderate correlation of the k1 value and a very weak correlation of the $\mathrm{k} 2$ value with the winter minimum air temperature.

Table 2. Characteristics of significant correlation coefficients of weather conditions with the fruitfulness coefficients $\mathrm{k} 1$ and $\mathrm{k} 2$ in general

\begin{tabular}{|c|c|c|c|c|}
\hline \multirow[b]{2}{*}{ Index } & \multicolumn{4}{|c|}{ Relationship } \\
\hline & $\begin{array}{c}\text { No relation } \\
\mathrm{r}<0,2\end{array}$ & $\begin{array}{c}\text { Very weak } \\
0,2 \leq \mathrm{r}<0,3\end{array}$ & $\begin{array}{c}\text { Weak } \\
0,3 \leq \mathrm{r}<0,5\end{array}$ & $\begin{array}{c}\text { Moderate } \\
0,5 \leq \mathrm{r}<0,7\end{array}$ \\
\hline $\mathrm{k} 1$ & Max T (VI) & $\begin{array}{l}\text { Min (Flo-Ver), Max } \\
\text { (Flo-Ver), Min (VI), A } \\
\text { (VII), RH (VII), RH } \\
\text { (VI-VII), Min } T \\
\text { (VI-VII), Avg T (VI-X), } \\
\text { TP (I-II) }\end{array}$ & $\begin{array}{l}F L O, \quad V E R, \text { A (Flo-Ver) A } \\
\text { (VI), A (VI-VII), Min T } \\
\text { (VI-X), A (VI-X), Avg T } \\
\text { (VI-XI), A (VI-XI), Sum T }{ }_{10} \\
\text { (VI-XI), Min T (XII-II), Avg } \\
\text { T (I-II) }\end{array}$ & Min T (VI-XI) \\
\hline $\mathrm{k} 2$ & $\begin{array}{l}\operatorname{Max}(\text { Flo-Ver), } \\
\text { (VI-X), Avg T }\end{array}$ & $V E R, \mathrm{~A}(\mathrm{VI})$ & $\begin{array}{l}\text { FLO, Min (Flo-Ver), } \\
\text { Min (VI), Min T (VI-VII), Min } \\
\text { T (VI-X), }\end{array}$ & \\
\hline
\end{tabular}




\begin{tabular}{|l|ll|l|l|l|}
\hline & $\begin{array}{l}\text { (VI-X), } \\
\text { (VI-XI) }\end{array}$ & $\begin{array}{l}\text { Max T (VI), Max (VII), } \\
\text { Avg T (VI-XI), Sum T } \\
\text { (VI-XI), Min T (XII-II) }\end{array}$ & Min T (VI-XI), Avg T (I-II) & \\
\hline
\end{tabular}

\section{Conclusion}

The results of this study, based on a correlation analysis, show a greater relationship between the fruitfulness coefficients $\mathrm{k} 1$ and $\mathrm{k} 2$ the temperature of the previous year (average, maximum, minimum air temperatures and the average air temperature amplitude), and less with the water availability characteristics. High values of correlation coefficients are a sign of high adaptability of grape varieties to the agroecological conditions of the south Russia In the place of their origin. These varieties include: Beysug, Mitsar, Cabernet AZOS, Krasnostop AZOS, Satsimler.

There are variety-specific relationships, including varieties with the same parents (Antaris and Satsimler, Alcor and Mitsar).

Winter weather has less influence on the fruitfulness coefficients values, when assessing the correlation coefficients for varieties due to the resistance of most varieties to frost and a rare drop in air temperature below $-20{ }^{\circ} \mathrm{C}$ during the study period $2007-2020$. However, in general, the winter period, as well as the period of initiation and differentiation of inflorescences, affects the fruitfulness coefficients values.

\section{Acknowledgments}

The reported study was funded by RFBR, project number 20-316-90016.

\section{References}

1. J.A. Santos, H. Fraga, A.C. Malheiro, J. Moutinho-Pereira, L.-T. Dinis, C. Correia, M. Moriondo, L. Leolini, C. Dibari, S. Costafreda-Aumedes, et al, Appl. Sci., 10, 3092 (2020)

2. J.C. Morrison. Bot. Gaz., 152, 304 (1991)

3. M. Keller, The Science of Grapevines. Third Edition, 542 (2020)

4. J.A. Santos, R. Costa, H. Fraga. Clim. Chang., 140, 273 (2017)

5. D. Molitor, M. Keller, OENO One, 50, 245 (2016)

6. G. Gutiérrez-Gamboa, W. Zheng, F.M.de Toda. Food Research International, 139, 109946 (2021)

7. D. Mosetti, J.C. Herrera, P. Sabbatini, A. Green, G. Alberti, E. Peterlunger, K. Lisjak, S.D. Castellarin, Vitis, 55(2), 57 (2016)

8. M.S. Smith, M. Centinari, American Journal of Enology and Viticulture, 70(3), 308 (2019)

9. A. Naor, Y. Gal, B. Bravdo, Journal of the American Society for Horticultural Science, 127(4), 628 (2002)

10. D.B. Terry, S.K. Kurtural, American Journal of Enology and Viticulture, 62(4), 426 (2011)

11. J.P. Geller, S.K. Kurtural. American Journal of Enology and Viticulture, 64(1), 65 (2013)

12. N. Torres, J. Martínez-Lüscher, E. Porte, R. Yu, S.K. Kurtural, Food Chemistry, 343, $128447(2021)$ 
13. V.S. Petrov, T.P. Pavlyukova, Fruit growing and viticulture of South Russia, 51(3), 129 (2018)

14. K.V. Smirnov, L.M. Maltabar, A.K. Radzhabov, N.V. Matuzok, N.V. Troshin Vinogradarstvo, 500 (2017) 